\title{
Pallister-Killian syndrome: additional manifestations of cleft palate and sacral appendage
}

\author{
D Ross McLeod, Linda R Wesselman, David I Hoar
}

\begin{abstract}
We report a case of Pallister-Killian syndrome in a 28 week gestation infant. In addition to the characteristic phenotype, this patient had a cleft palate, diaphragmatic hernia, sacral appendage, and imperforate anus. The lymphocyte karyotype showed $96 \% 46, \mathrm{XX} / 4 \% \quad 47, \mathrm{XX}+\mathrm{i}(12 \mathrm{p})$ and the fibroblast karyotype 47,XX,+marker (presumed i(12p)). Fibroblast cytogenetic studies should be considered in all cases of diaphragmatic hernia associated with other malformations.
\end{abstract}

Since the first report by Pallister, over 30 cases of isochromosome $12 p$ mosaicism have been described and the characteristic phenotype defined of a coarse face, flat, broad nasal bridge, hypertelorism, sparse scalp hair, short neck, limb abnormalities, irregular pigmentation, and developmental delay. ${ }^{1-5}$ There have been two reports ${ }^{67}$ in addition to our case of neonatal deaths in the syndrome with the malformations forming a consistent pattern of diaphragmatic hernia (3/3) and anorectal abnormalities (2/3). In addition, a case therapeutically aborted had a diaphragmatic hernia incompatible with life. ${ }^{7}$

We report a further case of isochromosome $12 p$ mosaicism with a diaphragmatic hernia, imperforate anus, cleft palate, and a sacral appendage.

\section{Case report}

The parents of the patient were in good health and unrelated. The mother was aged 24 and the father 26 at the time of delivery. The pregnancy was complicated by polyhydramnios and vaginal spotting at 8 weeks. There was no medication taken, she had an occasional

Division of Medical Genetics, Department of Paediatrics, Faculty of Medicine, University of Calgary, Alberta Children's Hospital Research Centre, Alberta Children's Hospital, Calgary, Canada.

D R McLeod, L R Wesselman, D I Hoar

Correspondence to $\mathrm{D} \mathbf{R}$ McLeod, Division of Medical Genetics, Alberta Children's Hospital Research Centre, 1820 Richmond Road SW, Calgary, Alberta, Canada T2T 5C7.

Received for publication 26 November 1990.

Accepted for publication 12 December 1990. drink containing alcohol, and 5 to 6 cigarettes per day. Prenatal vitamins were taken once daily. Labour was premature and delivery occurred at 28 weeks. The Apgar scores were 2 at one and five minutes and the infant was transferred to the Neonatal Intensive Care Nursery. A chest $x$ ray showed a left diaphragmatic hernia with bowel in the left of the chest and the heart displaced to the right.

The head circumference (OFC) was $27 \mathrm{~cm}$ (75th centile), length $38 \mathrm{~cm}$ (75th centile), and weight 1430 g (90th centile). The ears were small and low set. There was hypertelorism (inner canthal distance 1.8 $\mathrm{cm}$ ) and a broad, flat nasal bridge. A midline ridge was present in the maxillary ridge anteriorly (fig 1 ). The palate had a small posterior cleft. The neck was short with increased posterior neck skin and webbing. Both nipples were hypoplastic and inverted with an internipple distance of $5.4 \mathrm{~cm}$ (about +2 SD). The anus was absent with a sacral appendage of $1.5 \mathrm{~cm}$ present (fig 2). There was decreased range of movement at the elbows and hips. The hands were square with lymphoedema of the fingers. The thumbs were proximal and held in an adducted position. Oedema was also marked over the thighs.

There was a simian crease on the right hand. The infant died at 3 hours of age from pulmonary

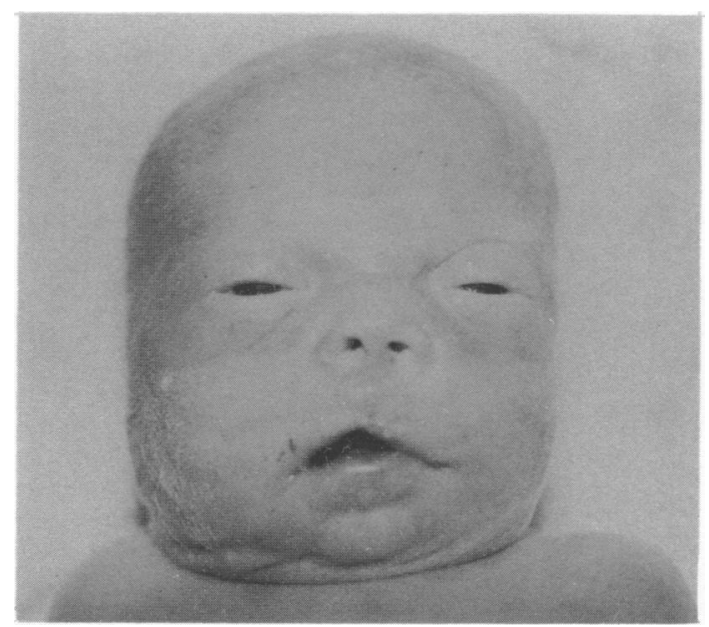

Figure 1 Facial appearance. 
Details of cases with Pallister-Killian syndrome and diaphragmatic hernia.

\begin{tabular}{|c|c|c|c|c|c|}
\hline & \multicolumn{3}{|c|}{ Neonatal lethal } & \multicolumn{2}{|c|}{ Terminations } \\
\hline & $\begin{array}{c}\text { Case } 1, \\
\text { Warburton } \text { et } a l^{7}\end{array}$ & Present case & Pauli et $a l^{b}$ & Lopes et al, ${ }^{9}$ Wyatt $^{10}$ & $\begin{array}{c}\text { Case } 3, \\
\text { Warburton } e t a l^{7}\end{array}$ \\
\hline Blood karyotype & Not done & $\begin{array}{l}\text { Mosaicism } \\
4 \% \text { abnormal }\end{array}$ & $\begin{array}{l}\text { Mosaicism } \\
10 \% \text { abnormal }\end{array}$ & $\begin{array}{l}\text { Mosaicism } \\
14 \% \text { abnormal }\end{array}$ & \\
\hline Skin karyotype & $\begin{array}{l}\text { Mosaicism } \\
90 \% \text { abnormal }\end{array}$ & $\begin{array}{l}47, \mathrm{XX}, \mathrm{i}(12 \mathrm{p}) \\
100 \%\end{array}$ & & $\begin{array}{l}\text { Mosaicism } \\
96 \% \text { abnormal }\end{array}$ & \\
\hline Other karyotype & & & $\begin{array}{l}\text { Gonad } \\
100 \% \text { abnormal }\end{array}$ & $\begin{array}{l}\text { Amniocytes } \\
\text { first } 100 \% \text { abnormal, } \\
\text { second mosaicism }\end{array}$ & $\begin{array}{l}\text { Amniocytes- } \\
\text { mosaicism } \\
\text { CVS-46,XX }\end{array}$ \\
\hline Diaphragmatic hernia & Left side & Left side & Left side & Massive & Large \\
\hline Anorectal anomalies & - & $\begin{array}{l}\text { Imperforate anus, } \\
\text { sacral appendage }\end{array}$ & $\begin{array}{l}\text { Imperforate } \\
\text { anus }\end{array}$ & - & - \\
\hline $\begin{array}{l}\text { Cleft lip/palate } \\
\text { or cleft palate }\end{array}$ & - & Cleft palate & $\begin{array}{l}\text { Cleft lip } \\
\text { and palate }\end{array}$ & - & - \\
\hline
\end{tabular}

hypoplasia. Necropsy confirmed the pulmonary hyponlasia and showed a blindly ending sigmoid colon and small foci of calcification in the pituitary.

\section{CYTOGENETIC STUDIES}

Chromosome analysis was performed on blood and skin. The blood showed a mosaic picture with $48 / 50$ cells $46, \mathrm{XX}$ and $2 / 50$ cells $47, \mathrm{XX},+$ iso(12p) (fig 3) while the skin fibroblast (passage number 4) karyotype was $15 / 1547, \mathrm{XX}$, + marker. Parental karyotypes were normal.

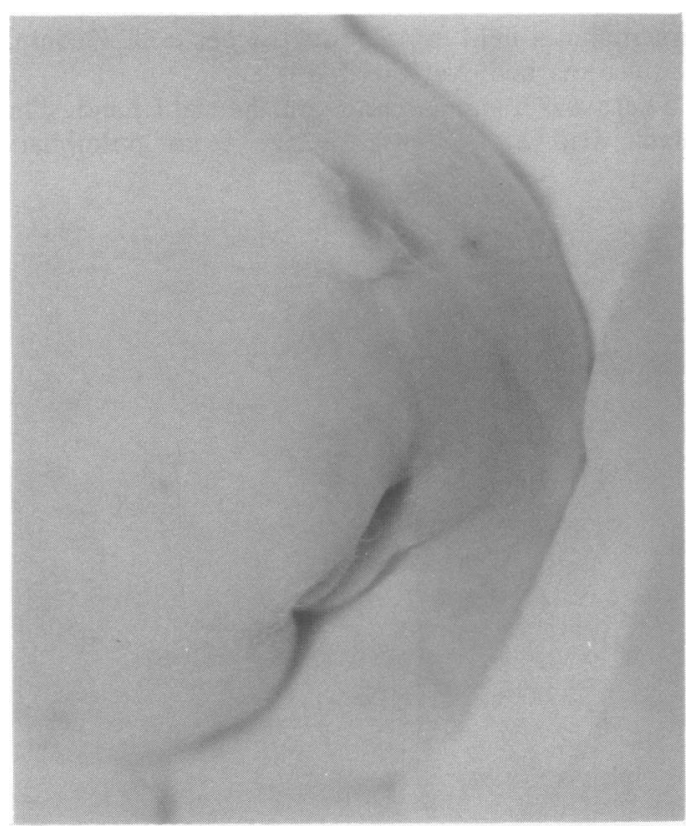

Figure 2 Sacral appendage.

\section{Discussion}

This patient has cleft palate and a sacral appendage as additional manifestations of isochromosome $12 p$ mosaicism and substantiates the association with imperforate anus and diaphragmatic hernia. Details of the four published cases and our case are summarised in the table. The finding of a percentage of cells in the blood with isochromosome $12 p$ is common with diaphragmatic hernia (3/5) and rare if diaphragmatic hernia is not present. ${ }^{3}$ There are two possible explanations for this; either the more widespread presence of mosaic tissue disrupts the development of the diaphragm or cases with early neonatal death only have fibroblast karyotypes if the lymphocytes show mosaicism. The usual approach to neonates with lethal multiple congenital malformations is to take blood and skin for karyotyping. If the lymphocyte karyotype is normal then an additional fibroblast karyotype is rarely done. It is therefore possible that the cases with isochromosome $12 p$ only in fibroblasts would be missed. This is important as there is overlap in the features of Fryns syndrome and cases of Pallister-Killian syndrome with diaphragmatic hernia. The major features of Fryns syndrome are diaphragmatic hernia, coarse face with a broad, flat nasal bridge, cleft lip/palate, hirsutism, and distal limb abnormalities. Less frequent features include short neck, corneal clouding, narrow thorax, hypoplastic nipples, excess neck skin, genital abnormalities, cystic renal dysplasia, and central nervous system malformations. ${ }^{8}$ The features which may distinguish the two conditions are corneal clouding in Fryns syndrome and sparse scalp hair in Pallister-Killian syndrome. As neither of these features is invariably present, we suggest that infants with diaphragmatic hernia and other malformations should have skin fibroblast karyotype analysis to avoid confusion with 


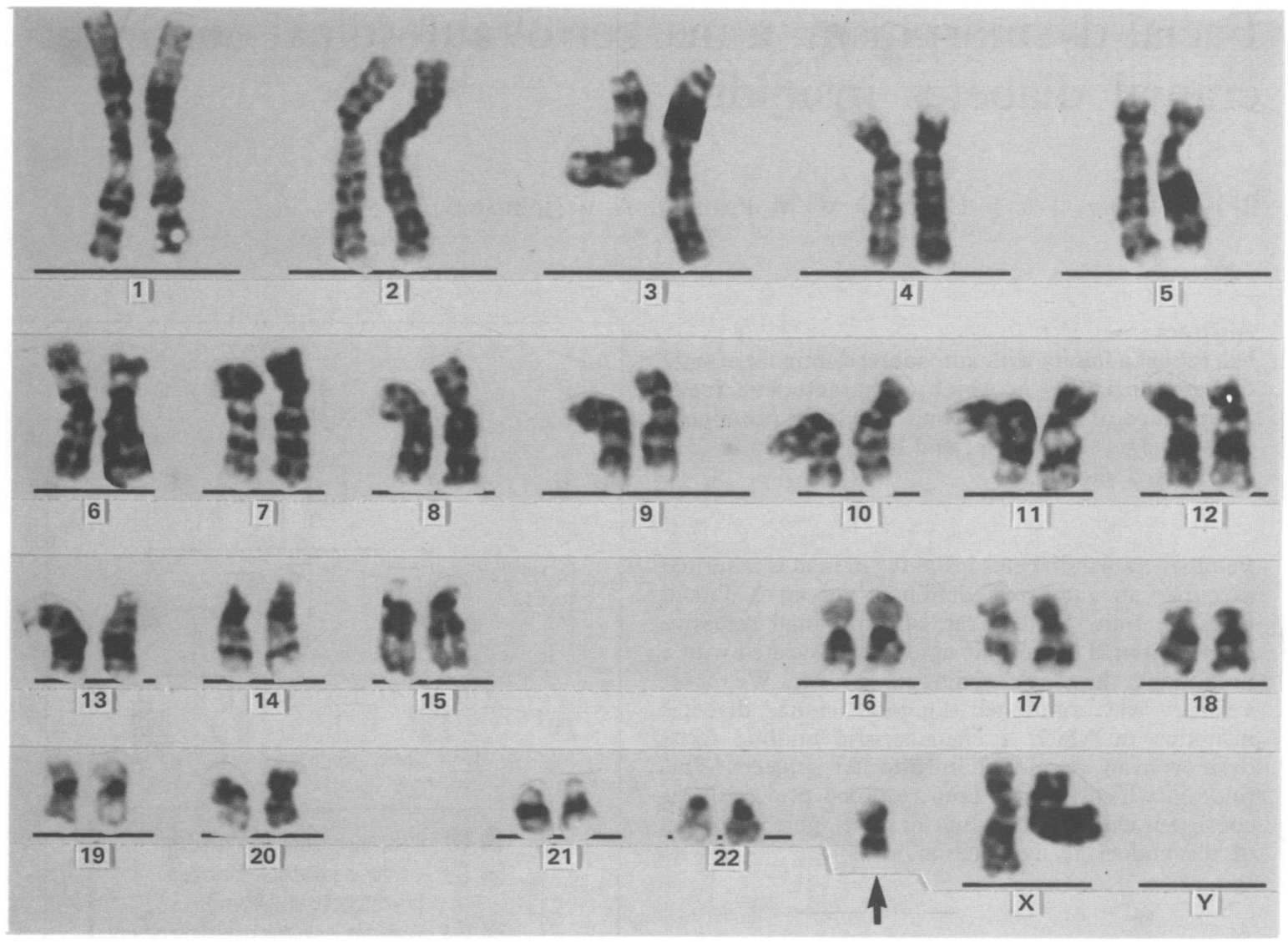

Figure 3 Karyotype 47,XX, +iso(12p).

Fryns syndrome. This is important in counselling, as the recurrence risk for Pallister-Killian is negligible but for Fryns syndrome it is $25 \%$.

1 Pallister PD, Melsner LF, Elejalde BR, et al. The Pallister mosaic syndrome. In: Bergsma D, Lowry RB. eds. New syndromes. New York: Alan R Liss, for the National Foundation-March of Dimes. Birth Defects 1977;XIII (3B): 103-10.

2 Buyse ML. Killian syndrome, Pallister mosaic syndrome, or mosaic tetrasomy 12p? An analysis. 7 Clin Dysmorphol 1983;1: 2-5!

3 Killian W, Zonana J, Schroer RJ. Abnormal hair, craniofacial dysmorphism, and severe mental retardation-a new syndrome? f Clin Dysmorphol 1983;1:6-13.

4 Hunter AGW, Clifford B, Cox DM. The characteristic physiognomy and tissue specific karyotype distribution in the PallisterKillian syndrome. Clin Genet 1985;28:47-53.
5 Reynolds JF, Daniel A, Kelly TE, et al. Isochromosome 12p mosaicism (Pallister mosaic aneuploidy or Pallister-Killian syndrome): report of 11 cases. Am $\mathcal{F}$ Med Genet 1987;27: 257-74.

6 Pauli RM, Zeier RA, Sekhon GS. Mosaic isochromosome 12p. Am $\mathcal{F}$ Med Genet 1987;27:291-4.

7 Warburton D, Anyane-Yeboa K, Francke U. Mosaic tetrasomy $12 \mathrm{p}$ : four new cases and confirmation of the chromosomal origin of the supernumerary chromosome in one of the original Pallister-mosaic syndrome cases. Am $\mathcal{f}$ Med Genet 1987;27: 275-83.

8 Moerman P, Fryns JP, Vandenberghe K, Devlieger H, Lauweryns $J M$. The syndrome of diaphragmatic hernia, abnormal face and distal limb anomalies (Fryns syndrome): report of two sibs with further delineation of this multiple congenital anomaly (MCA) syndrome. Am F Med Genet 1988;31:805-14.

9 Lopes V, Mak E, Wyatt PR. Prenatal diagnosis of tetrasomy 21. Prenat Diagn 1985;5:233-5.

10 Wyatt PR. Pallister-Killian syndrome-an update of a clinical case. Am $\mathcal{f}$ Med Genet 1988;29:229. 